\title{
Holocarboxylase Synthetase Deficiency
}

National Cancer Institute

\section{Source}

National Cancer Institute. Holocarboxylase Synthetase Deficiency. NCI Thesaurus. Code C98842.

A rare autosomal recessive inherited disorder caused by mutations in the HLCS gene. It is characterized by deficiency of the enzyme holocarboxylase synthetase which facilitates the effective use of the vitamin biotin in the body. Signs and symptoms appear early in life and include breathing difficulties, feeding difficulties, alopecia, skin rash, and lethargy. Lifelong administration of biotin supplements is required. If it is not treated properly, it may lead to developmental delays, seizures, and coma. 